\title{
Financial Services Strategies in the Euro-Zone
}

\author{
Ingo Walter ${ }^{1}$
}

\section{The new euro environment}

Introduction of the euro certainly represents a sea-change in the environment of modern global finance. In the three decades since the end of the Bretton Woods system in 1971, and against great odds, Europe has forged a platform that could ultimately emerge as a viable challenger to the United States as the world's premier financial market. It was a difficult birth - but if ever the saying "no pain, no gain" applies in context of macro-financial reform, this is it. ${ }^{2}$

Financial institutions are extraordinarily sensitive even to small changes in the environment. Increases in interest-rate or exchange-rate volatility can create wholly new markets for risk-management products, just as surely as these businesses - often builtup at huge expense - can be wiped-out overnight if volatility drops. Regulatory concerns about counterparty or liquidity risk in over-the-counter markets can quickly drive transactions onto organized exchanges and their standardized contracts, and eliminate much of the innovation that is most easily undertaken in interprofessional OTC markets. Similar stories could be related to changes in tax codes, transaction-costs, information technologies, and an array of other variables that form the environmental overlay of business strategy in the financial services industry. These are parameters that management has to carefully think through, build a consensus on, and then place its strategic bets. When mistakes are made in devising core strategies in the financial services industry, they are usually big ones.

${ }^{1}$ Charles Simon Professor of Applied Financial Economics and Director, New York University Salomon Center. Paper presented at a European Investment Bank conference on European Banking After EMU, Luxembourg, 21 January 1999. Draft of February 2, 1999.

${ }^{2}$ See for example Story and Walter [1997]. 
The advent of the euro is probably the most important current development in the environment of the world's financial institutions, and therefore has to be carefully related to the strategies of financial firms. Other contemporary issues, such as emerging market financial crises, regulation of hedge funds, and Japan's continued economic doldrums pale by comparison. The euro will redefine a large part of the global financial landscape of the $21^{\text {st }}$ century. Strategies of European financial services firms in their home markets have already been profoundly affected by competitive conditions that have yet to be fully delineated. Meanwhile outsiders, notably American firms long used to competing in a massive single-currency market, have big strategic plans for the euro-zone. In some cases they have already made incursions into European financial services markets that would have been undreamed-of a few years ago. As financial reconfiguration in the euro-zone proceeds alongside continued technological advance in both the wholesale and retail domains, as regulatory and tax policy alignment continues to change the rules of the game, and as clients become increasingly performance-oriented and promiscuous, core strategies of financial firms - many of whom continue to think in terms of institutional boundaries instead of financial processes - will come under additional stress.

This paper begins with a series of suppositions - essentially maximum-likelihood state-variables relating to financial system conditions in the euro-zone, assuming a fiveyear time horizon. These suppositions set the framework for a discussion of strategic positioning and implementation on the part of financial services firms expecting to compete successfully in the euro-zone. We focus on the institutional microstructure of the financial intermediation process and the determinants of competitive performance. This is followed by an assessment of strategic options facing financial firms in the eurozone, and alternative institutional outcomes from the perspective of efficiency and stability of the euro-zone financial system. Where appropriate, comparisons are drawn with the U.S. financial system, which has operated under a single currency since 1865. The final section of the paper provides some strategy and policy indications for the future.

\subsection{Suppositions}

Any competent strategic exercise aiming at creating and sustaining a highperformance financial services franchise in the euro-zone has to start by taking a view on the basic drivers of financial markets - as well as various regulatory overlays - and their impact on the prospective size and structure of the market for wholesale and retail financial services. If some of management's suppositions turn out to be wrong, expensive and possibly debilitating strategic mistakes may be the result. Box 1 presents the likely impact on financial markets of the introduction of the euro.

If these environmental suppositions are broadly borne-out by the facts, the eurozone market for financial services is likely to be a very dynamic one indeed, both in terms of its overall prospects within the broader context of the global financial system and in terms of its structure. This runs across the entire spectrum of wholesale and retail financial activities. There is plenty of growth potential in wholesale capital market activities as the new government bond market envelops the constituent national markets and as the corporate and asset-backed bond markets accelerate the 


\section{Box 1- Supposition}

\section{The Government Bond Market}

Eleven euro-zone government bond markets, estimated at $\$ 1.9$ trillion in 1998, are roughly comparable in size to the United States. There will be growing standardization of government bonds in the euro-zone, including auction calendars and interest calculations, as well as new instruments such as inflation-indexed bonds denominated in euros.

The changed fiscal environment will constrain the issuance of national government bonds and the rate of growth of the market, and push financing onto municipalities and other public inance entities, sometimes with state guarantees.

Trading in euro-zone government bonds, driven historically by interest rate and exchange rate factors among the participating countries are likely to be driven mainly by credit spreads in the future. The $23 \mathrm{bp}$ and $20 \mathrm{bp}$ spread between Germany and Portugal and Belgium, respectively, at the end of 1998 are far smaller than those between the states in the U.S. will be fubject to convi ballouts, hese may be too nanow. Euro-zone government bonds by home-country government spreads.

\section{The Corporate Bond Market}

The euro-zone corporate bond market was estimated at $\$ 160$ billion in 1998, one-sixth the size of the United States, with limited liquidity. Outstandings may rise to $\$ 800$ billion over ten years as capital market financing replaces bank financing, as a high-capacity, liquid euro-zone market replaces fragmented national markets, and as national investment restrictions are scrapped.

Incremental demand for assets denominated in euros can be expected to lower average interest rates and the cost of capital facing euro-zone corporations even in the presence of growing demand for financing in euros. Increased trading volume and market liquidity will reduce transactions costs for investors and issuers.

The market for non-investment grade debt in Europe has already grown rapidly as investors search for yield and as the financing requirements of small, high-growth companies increase, development that is likely to continue in the foreseeable future.

The market for asset-backed securities in the euro-zone, very small in comparison to that in the United States, will grow rapidly as various tax and regulatory impediments are removed, and as banks rethink how much capital they should have tied-up in their lending book. Already some of the pioneering securitization of commercial loans has taken place in Europe, with significant mutual gains for borrowers, investors and intermediaries.

\section{The Market for Equities}

Euro-zone equity market capitalization was estimated to be $\$ 2.5$ trillion in mid-1998, compared to about $\$ 10$ trillion in the United States, with various forecasts pointing to a tripling over a decade or so. The euro-zone's 32 stock exchanges in 1998 (compared to 8 in the U.S.) and 23 derivatives exchanges (compared to 7 in the U.S.) will consolidate rapidly even as trading, clearance and settlement systems become more efficient.
Secondary markets for equities in the euro-zone will increasingly be characterized by blocktrading, as large institutional investors grow in importance, and with it the need for risk management, capital and institutional distribution capability. There will be growing use of innovative equity-linked financial instruments and structured transactions for which the national European markets were previously too small, too fragmented and illiquid, too tightly regulated or too uncompetitive to make them attractive.

The creation of euro-equity benchmarks like the Dow Jones Euro Stoxx 50 and the FTSE Eurotop 100 will strengthen performance orientation of asset managers as well as corporations, promoting the shift from national to sectoral asset allocation.

Accelerated development of IPOs and the small-cap equity market can be foreseen, promoted by the success of markets such as Nouveau Marché in France and Neuer Markt in Germany, as well as growth in the volume of MBOs, LBOs, venture capital and private equity.

\section{Retail Financial Services}

Retail financial services markets in the euro-zone will change only gradually, due to wide differences in preferences and the historical dominance of certain types of institutions such as savings banks, mortgage banks, cooperative banks and postal savings banks, as well as equally significant differences in the insurance industry.

New products and retail distribution channels will gradually encroach on legacy structures, they have already done in the case of bancassurance, which will gradually make the retail financial services market more open to competition, both cross-border and between domestic strategic groups.

As demographics confront heavy reliance in most euro-zone countries on unfunded (pay-asyou-go) or underfunded pension schemes, governments are being forced to introduce prefunded pension systems. New schemes will focus on defined contribution formulas that shif management responsibility to beneficiaries, suggesting a growing role for mass-distribution and branding of pension products. This will eventually form massive, performance-driven managed pools of fixed-income securities and equities. As involuntary "noise" traders, these will make a disproportionate contribution to euro-zone financial market liquidity and efficiency (see Walter, 1999)

The euro-zone mutual fund industry will be contested by banks, insurance companies, independent fund management companies, as well as financial conglomerates. However, retail financial services in the euro-zone will be subject to strong consumer protection measures at the national level, which may retard penetration of non-traditional and innovative products and distribution channels.

Secondary markets for equities in the euro-zone will increasingly be characterized by block- 
replacement of bank debt, as it has done in the United States. Equity markets should develop rapidly as well, propelled by rising volumes of new issues and an expanding need for equities in pre-funded pension plans as some of the euro-zone countries come to grips with the demographic reality of aging populations. Economic sectors, individual corporate prospects, and credit quality will replace currencies in asset allocation strategies. And at the retail level, clients will face an increasing array of financial services from a wide variety of vendors using traditional and nontraditional approaches to distribution, with local and regional financial services oligopolies confronting unprecedented challenge.

The potential for change brought about by the euro is set against a state of substantial overcapacity and inefficiency in broad segments of the euro-zone's financial services industry. There is too much capital and there are too many people employed in the production and distribution of financial services - as there have been in the United States. Both will be removed in a process of restructuring and consolidation that has only just begun. It will take a long time, most particularly in the retail sector in view of the importance of government-related and cooperative institutions in Europe that are not subject to the shareholder-value discipline. The ruthlessness of the U.S. restructuring process will be missing, and this is likely to retard the movement to a new equilibrium in terms of financial structure. And of course nobody wants to be shaken-out, so tenacious rear-guard actions will be mounted by vulnerable players even as new entrants including the ubiquitous Americans hardened by their own structural revolution - crowd into the European marketplace.

Table 1 shows some of the differences between European and U.S. financialsector restructuring via mergers and acquisitions (M\&A), with U.S. intra-sector M\&A volume during the period 1985-97 almost three times the European volume in banking, three times as large in securities and twice as large in insurance. This despite the fact that the EU plus Switzerland comprises a larger economic region than the United States. Inter-sector M\&A volume was higher in Europe for banks buying insurance companies, presumably due to the popularity of bancassurance and the absence of legal barriers. Table 2 shows the cross-border aspects of financial services M\&A activity. Most important among U.S. acquisitions abroad are investment firms buying other investment firms (notably British merchant banks and asset managers) and insurance companies buying foreign insurance companies. Intra-European cross-border transactions are mainly intra-sectoral, with almost half occurring in the insurance industry. When European firms acquire non-European ones (mainly in the United States and Japan), this is again largely on an intra-sector basis.

Developing and implementing strategies in firms hoping to secure a permanent and profitable place in the coming euro-zone financial services configuration thus presents challenges that will test the mettle of even the most far-sighted and determined managers. It centers around seven basic questions:

- $\quad$ Strategic positioning. Given the foregoing environmental suppositions governing the euro-zone, what are the target markets - in terms of clients, products and geographic spread - that promise the most attractive opportunities for growth over time? 
Table 1

Volume of In-Market Mergers \& Acquisitions in the United States and Europe, 1985-98 (billions of U.S. dollars and percent)

Target Institution

\begin{tabular}{|c|c|c|c|c|c|c|}
\hline \multirow[b]{2}{*}{$\begin{array}{l}\text { Acquiring } \\
\text { Institution }\end{array}$} & \multicolumn{3}{|c|}{ U.S. } & \multicolumn{3}{|c|}{ Europe } \\
\hline & Banks & Securities & Insurance & Banks & Securities & Insurance \\
\hline $\begin{array}{l}\text { Commercial } \\
\text { Banks }\end{array}$ & $\begin{array}{c}435 \\
(53.4 \%)\end{array}$ & $\begin{array}{c}18 \\
(2.2 \%)\end{array}$ & $\begin{array}{c}0.2 \\
(0.0 \%)\end{array}$ & $\begin{array}{c}186 \\
(36.9 \%)\end{array}$ & $\begin{array}{c}16 \\
(3.2 \%)\end{array}$ & $\begin{array}{c}21 \\
(4.2 \%)\end{array}$ \\
\hline $\begin{array}{l}\text { Securities } \\
\text { Firms }\end{array}$ & $\begin{array}{c}6 \\
(0.7 \%)\end{array}$ & $\begin{array}{c}98 \\
(12.0 \%)\end{array}$ & $\begin{array}{c}29 \\
(3.6 \%)\end{array}$ & $\begin{array}{c}27 \\
(5.4 \%)\end{array}$ & $\begin{array}{c}31 \\
(6.2 \%)\end{array}$ & $\begin{array}{c}31 \\
(6.1 \%)\end{array}$ \\
\hline $\begin{array}{l}\text { Insurance } \\
\text { Companies }\end{array}$ & $\begin{array}{c}73 \\
(9.0 \%)\end{array}$ & $\begin{array}{c}15 \\
(1.9 \%)\end{array}$ & $\begin{array}{c}140 \\
(17.2 \%)\end{array}$ & $\begin{array}{c}45 \\
(9.0 \%)\end{array}$ & $\begin{array}{c}9 \\
(1.8 \%)\end{array}$ & $\begin{array}{c}137 \\
(27.2 \%)\end{array}$ \\
\hline
\end{tabular}

Source: DeLong, Smith and Walter [1999] 
Table 2

Volume of Cross-Market Mergers \& Acquisitions in the United States and Europe, 1985-98

(billions of U.S. dollars and percent)

Target Institution

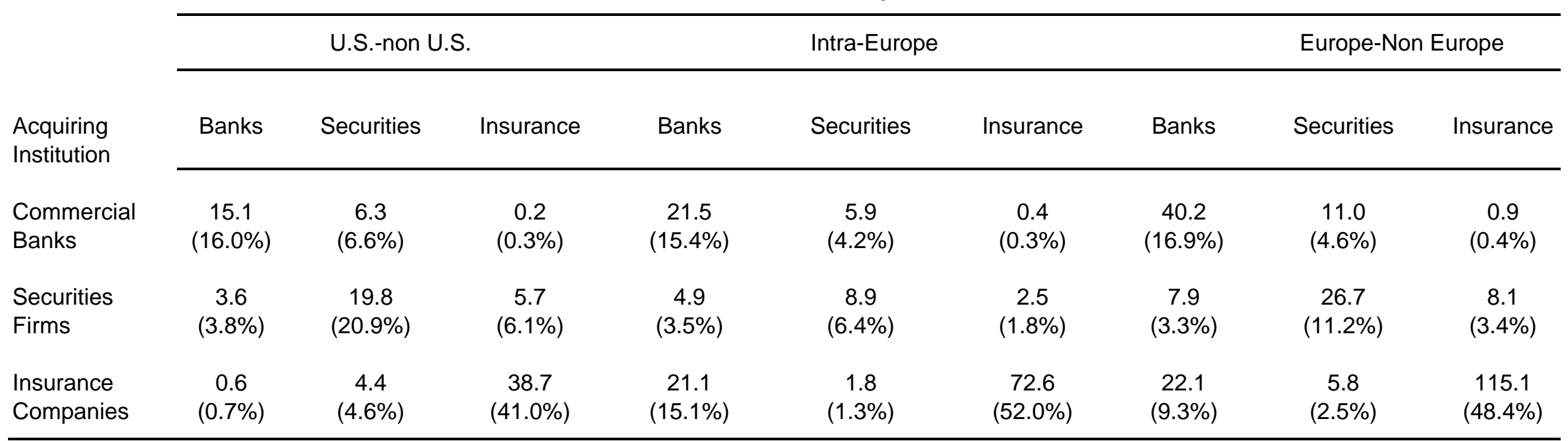

Source: DeLong, Smith and Walter [1999] and Securities Data Company. The first figure is the dollar value (in billions) of M\&A activity and the second number in parentheses is the percentage of the total (these sum to 100 for each $3 \times 3$ matrix). Figures reported are the sum of the equity values of the target insitutions. 
$\longrightarrow$

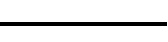

$\longrightarrow$ 
- $\quad$ Prospective market structure. How are these targeted markets likely to evolve over time in terms of competitive structure? There is not much sense in going through the effort and expense of gearing up - for what looks like a potentially profitable market if, at the end of the day, competitors are doing the same thing and market structure ends up approximating perfect competition, incapable of supporting attractive, sustained returns on the capital employed. Herd-like behavior is well known among financial services managers and strategists, especially in the face of major parameter-shocks like creation of the euro-zone, and it may be advisable to stay out of the way of the stampede.

- Core competencies. What is the firm really good at, in terms of its baseline market position and franchise, creativity and innovation, flexibility, ability to manage complexity, command of financial and human resources? What competitive resources can be rolled-out geographically or focused on defensible market segments in response to euro-zone developments?

- Operating economies. To what extent are there economies of scale, cost economies of scope and production-efficiencies that can be exploited in order to reinforce the firm's competitive position?

- Revenue synergies and earnings diversification. Are there revenue economies of scope that can be exploited by linking products and clients, and are these crossselling gains likely to prevail across the euro-zone for target retail and/or wholesale client segments? Relatedly, are there significant earnings-stability gains to be had by diversifying across clients, financial services activities and geographies within the euro-zone?

- Institutional configuration. What types of institutional configurations do the strategic positioning considerations suggest are the ones most likely to maximize the value of the enterprise, running across the institutional spectrum from massive euro-zone universals or multifunctional financial services conglomerates to specialists that are highly focused on best-in-class delivery of specific types of financial services?

- $\quad$ Ability to execute. Based on the firm's existing situation and an objective assessment of competitive strengths and weaknesses - a "reality check" - is it reasonable to envision its transformation into what will be required in the light of the environmental suppositions, given resource and managerial constraints, with reasonable but not excessive urgency?

Financial intermediation in the countries comprising the euro-zone has traditionally been heavily dominated by commercial banks, insurance companies and savings institutions, together capturing about $85 \%$ of all financial assets in the system in 1998, compared with about $40 \%$ in the United States. If the same economics of disintermediation apply in both regions, one would expect the role of classic euro-zone intermediaries to decline dramatically over time. In order to "go with the flow" banks will have to develop viable strategies to compete in mutual fund management, pension fund 
management, capital market access, asset securitization, custody and securities transaction-processing, etc. So will insurance companies and savings institutions. And there will be plenty of room for specialists of various kinds. The financial services industry, in short, is beginning a profound shakeup which will ultimately settle into some sort of new institutional equilibrium, and nobody is quite sure yet how that will look. But if the United States is any sort of reasonable guide, it will be a highly varied and dynamic field of players.

\section{Searching for Operating Economies and Revenue Synergies}

As in many other industries, a major purported benefit associated with the advent of the euro is the realization for the first time of significant economies of scale and economies of scope. For the first time as well, an unprecedented degree of competitive pressure will bear on long-sheltered European financial firms, and force them to manage better. Regardless of scale or scope benefits, this will create a leaner, more cost-effective set of competitors to the benefit of their own shareholders and the European financial system.

Individually or in combination, economies (diseconomies) of scale and scope in euro-zone financial firms will lead to increased (decreased) profit margins or passed along to clients in the form of lower (higher) prices resulting in a gain (loss) of market share. They should be directly observable in cost functions of financial services suppliers and in aggregate performance measures. Unfortunately, studies of scale and scope economies in financial services are unusually problematic. ${ }^{1}$ The nature of the empirical tests used, the form of the cost functions, the existence of unique optimum output levels, and the optimizing behavior of financial firms all present difficulties. Limited availability and conformity of data present serious empirical problems. And the conclusions of any study that has detected (or failed to detect) economies of scale and/or scope in a sample selection of financial institutions does not necessarily have general applicability. Such difficulties notwithstanding, the potential impact of the euro on operating economics (production functions) of financial firms is so important - and so often used to justify mergers, acquisitions and other strategic initiatives - that available empirical evidence is central to the whole argument.

\subsection{Economies of Scale}

Whether economies of scale exist in financial services has been at the heart of strategic and regulatory discussions about optimum firm size in the financial services sector. Can increased average size of firms create a more efficient financial sector and can it increase shareholder value?

For example, large organizations may be more capable of the massive and "lumpy" capital outlays required to install and maintain the most efficient informationtechnology and transactions-processing infrastructures. If extremely high technology spend-levels result in higher efficiency, then large financial services firms will tend to

\footnotetext{
${ }^{1}$ For a recent survey, see Berger, Demsetz and Strahan [1998].
} 
benefit in competition with smaller ones. However, smaller organizations ought to be able to pool their resources or outsource scale-sensitive activities in order to capture such gains

In an information- and distribution-intensive industry with high fixed costs such as financial services, there should be ample potential for scale economies - as well as potential for diseconomies of scale attributable to disproportionate increases in administrative overhead, management of complexity, agency problems and other cost factors once very large firm-size is reached. If economies of scale prevail, increased size will help create systemic financial efficiency and shareholder value. If diseconomies prevail, both will be destroyed.

Examples of financial-sector megamergers in 1998 alone include Deutsche Bank and Bankers Trust as the first intercontinental mega-deal, creating the world's largest bank with combined assets of $\$ 849$ billion in November 1998, Swiss Bank Corporation and Union Bank of Switzerland in Europe to form UBS AG (\$749 billion), and Citibank and Travelers to form Citigroup (\$702 billion), Banco Santander and Banco Central Hispanoamericano to form BSCH ( $\$ 300$ billion) in January 1999 , as well as such major 1998 U.S. deals as First Chicago NBD and BancOne, and BankAmerica and NationsBank. Bankers regularly argue that "bigger is better" from both systemic and shareholder-value perspectives, and usually point to economies of scale as a major reason why. What is the evidence?

Many studies of economies of scale have been undertaken in the banking, insurance and securities industries over the years (see Saunders, 1996 for a survey). Estimated cost functions form the basis most of these empirical tests, virtually all of which have found that economies of scale are achieved with increases in size among small banks (below $\$ 100$ million in asset size). More-recent studies have shown the that scale economies may also exist in banks falling into the $\$ 100$ million to $\$ 5$ billion range. There is very little evidence so far of scale economies in the case of banks larger than $\$ 5$ billion. An examination of the world's 200 largest banks [Saunders and Walter, 1994] found evidence that very largest banks grew more slowly than the smaller among the large banks during the 1980s, but that limited economies of scale did appear among the banks included in the study. More recently, there is some scattered evidence of scalerelated cost gains of up to $20 \%$ for banks up to $\$ 25$ billion in size. [Berger and Mester, 1997] But according to a new survey of all empirical studies of economies of scale through 1998, there was no evidence of such economies among very large banks. [Berger, Demsetz and Strahan, 1998] The consensus seems to be that scale economies and diseconomies generally do not result in more than about $5 \%$ difference in unit costs.

Inability to find major economies of scale among large financial services firms is also true of insurance companies [Cummins and $\mathrm{Zi}, 1998$ ] and broker-dealers [Goldberg, Hanweck, Keenan and Young, 1991]. And among German universal banks Lang and Wetzel [1998] found diseconomies of scale in both banking and securities services. Annex 1 shows the 20 largest European and U.S. banks, all of which are well are much larger than the size of banks for which any empirical evidence of scale economies has been found. The data also show the top-20 European banks to be much 
larger than the top-20 U.S. banks.

So, for most banks and nonbank financial firms in the euro-zone, except the very smallest among them, scale economies seem likely to have relatively little bearing on competitive performance. This is particularly true since many of the smaller European institutions are linked-together in cooperatives or other structures that allow harvesting available economies of scale centrally, or are specialists not particularly sensitive to the kinds of cost differences usually associated with economies of scale in the financial services industry. Big deals like those cited above and most of the megamergers that may appear in the euro-zone in coming years are unlikely, whatever their other merits may be, to contribute very much in terms of scale economies unless the fabled "economies of superscale" turn out to exist -- these, like the abominable snowman, have unfortunately never been observed in nature.

A basic fallacy, of course, is focusing on firm-wide scale economies when the really important scale issues are encountered at the level of individual financial services. There is ample evidence, for example, that economies of scale are both significant and important for operating economies and competitive performance in areas such as global custody, processing of mass-market credit card transactions and institutional asset management, but are far less important in other areas - private banking and M\&A advisory services, for example. Unfortunately, empirical data on cost functions that would permit identification of economies of scale at the product level are generally proprietary and therefore unavailable. Still, it seems reasonable that a scale-driven panEuropean strategy may make a great deal of sense in specific areas of financial activity even in the absence of evidence that there is very much to be gained at the firm-wide level.

\subsection{Economies of Scope}

There should also be potential for economies of scope in the euro-zone financial services sector - competitive benefits to be gained by selling a broader rather than narrower range of products - which may arise either through supply- or demand-side linkages.

On the supply side, scope economies involve cost-savings achieved through sharing of overheads and improving technology via joint production of generically similar services. Cost-diseconomies of scope may arise from such factors as inertia and lack of responsiveness and creativity that may come with increased firm size and bureaucratization, "turf" and profit-attribution conflicts that increase costs or erode product quality in meeting client needs, or serious cultural differences across the organization that inhibit seamless delivery of a broad range of financial services.

Most empirical studies have failed to find cost-economies of scope in the banking, insurance or securities industries, and most of them have concluded that some diseconomies of scope are encountered when firms in the financial services sector add new product-ranges to their portfolios. Saunders and Walter [1994], for example, found negative supply-side economies of scope among the world's 200 largest banks - as the product range widens, unit-costs seem to go up. 
Scope economies in most other studies of the financial services industry are either trivial or negative (see Saunders, 1996). However, the period covered by many of these studies involved institutions that were shifting away from a pure focus on banking or insurance, and may thus have incurred considerable costs in expanding the range of their activities. If this diversification effort involved significant front-end costs - which were expensed on the accounting statements during the period under study - that were undertaken to achieve future expansion of market-share or increases in fee-based areas of activity, then we might expect to see any strong statistical evidence of diseconomies of scope (for example, between lending and non-lending activities of banks) reversed in future periods. Investment in staffing, training, and infrastructure in fact bear returns in the future commensurate with these expenditures, then neutral or positive cost economies of scope may well exist. Still, the available evidence remains inconclusive.

On the revenue side, economies of scope attributable to cross-selling arise when the all-in cost to the buyer of multiple financial services from a single supplier including the cost of the service, plus information, search, monitoring, contracting and other transaction costs - is less than the cost of purchasing them from separate suppliers. Revenue-diseconomies of scope could arise, for example, through agency costs that may develop when the multi-product financial firm acts against the interests of the client in the sale of one service in order to facilitate the sale of another, or as a result of internal information-transfers considered inimical to the client's interests. Managements of universal banks and financial conglomerates often argue that broader product and client coverage, and the increased throughput volume and/or margins this makes possible, leads to shareholder-value enhancement.

Despite an almost total lack of hard empirical evidence, it is nonetheless reasonable to suggest that revenue economies of scope may indeed exist, but that these are likely to be very specific to the types of services provided and the types of clients served. Strong cross-selling potential may exist for retail and private clients between banking, insurance and asset management products (one-stop shopping), for example. Yet such potential may be totally absent between trade-finance and mergers and acquisitions advisory services for major corporate clients. So demand-related scope economies in the euro-zone are clearly linked to a firm's specific strategic positioning across clients, products and geographic areas of operation [Walter, 1988]. Indeed, a principal objective of strategic positioning in the "new" model of European financial services is to link market-segments together in a coherent pattern - what might be termed "strategic integrity"- that permits maximum exploitation of cross-selling opportunities, and the design of incentives and organizational structures to ensure that such exploitation actually occurs. These are, however, extraordinarily difficult to achieve and must work against multiple-vendor behavior on the part of corporate and institutional clients as well as a new generation retail clients comfortable with nontraditional approaches to distribution such as the Internet. $^{2}$

${ }^{2}$ Recent consumer surveys in the United States show that client reactions to multi-product vendor relationships are viewed very positively in principle, but in fact American retail clients have significantly increased the average number of financial services firms they deal with throughout the 1990s. 


\subsection{Production-efficiency}

Besides economies of scale and cost-economies scope, financial firms of roughly the same size and providing roughly the same range of services can have very different cost levels per unit of output. There is ample evidence of such performance differences, for example, in comparative cost-to-income ratios among banks or insurance companies or investment firms both within and between national financial-services markets. The reasons involve differences in production functions, efficiency and effectiveness in the use of labor and capital, sourcing and application of available technology, and acquisition of inputs, organizational design, compensation and incentive systems - i.e., in just plain better management.

Empirically, number of authors have found very large disparities in cost structures among banks of similar size, suggesting that the way banks are run is more important than their size or the selection of businesses that they pursue [Berger, Hancock and Humphrey, 1993; Berger, Hunter and Timme, 1993]. The consensus of studies conducted in the United States seems to be that average unit costs in the banking industry lie some $20 \%$ above "best practice" firms producing the same range and volume of services, with most of the difference attributable to operating economies rather than differences in the cost of funds [Akhavein, Berger and Humphrey, 1996]. Siems [1996] finds that the greater the overlap in branch-office networks, the higher the abnormal equity returns in U.S. bank mergers, while no such abnormal returns are associated with increasing concentration levels in the regions where the bank mergers occurred. This suggests that any shareholder value gains in many of the financial services mergers of the 1990s were more highly associated with increases in production efficiency (often termed X-efficiency) than with reductions in competition.

If very large institutions are systematically better managed than smaller ones (which may be difficult to document in the real world of financial services) then there may be a link between firm size and X-efficiency. In any case, both from a systemic and shareholder-value perspective, management is (or should be) under constant pressure though their boards of directors to do better, to maximize X-efficiency in their organizations and to transmit that pressure throughout the enterprise. If the euro-zone intensifies that pressure, this may in the end be one of the most significant sources of financial-sector performance gains.

Taken together, the available empirical suggests very limited prospects for firmwide cost economies of scale and scope among major financial services firms, and that X-efficiency seems to be the principal determinant of observed differences in cost levels among banks and nonbank financial institutions. Demand-side economies of scope through cross-selling may well exist, but are likely apply very differently to specific client segments and can be vulnerable to erosion due to greater client promiscuity in response to sharper competition and new distribution technologies. Based on these considerations alone, therefore, there appears to be room in the eurozone for viable financial services firms that range from large to small and from universal 
to specialist in a rich mosaic of institutions, as against a competitive monoculture dominated by financial mastodons.

\section{Prospective Market Structures in Euro-zone Financial Services}

In addition to the strategic search for operating economies and revenue synergies in the euro-zone financial services industry of the future, firms will also seek to dominate markets in order to extract economic rents. Europe has a long history of imperfect market structures and sometimes cartel formation in various industries, and the financial services market has been no different.

The role of concentration and market power in the financial services industry is an issue that empirical studies have not yet examined in great depth, although in many national markets for financial services, suppliers have shown a tendency towards oligopoly. Supporters have argued that high levels of national market concentration are necessary in order to provide a platform for a viable pan-European or global competitive position. Opponents argue that monopolistic market structures without convincing evidence of scale economies or other size-related gains serve mainly to extract economic rents from consumers or users of financial services and redistribute them to shareholders, cross-subsidize other areas of activity, or reduce pressures for costcontainment. They therefore advocate vigorous anti-trust action to prevent exploitation of monopoly positions. ${ }^{3}$

The key strategic issue is the likely future competitive structure of financial services in the euro-zone, since margins tend to be positively associated with higher concentration levels, as do cost-to-income ratios. Financial services market structures differ widely among countries, as measured for example by the Herfindahl-Hirshman index, ${ }^{4}$ with very high levels of concentration in countries such as the Netherlands, Finland and Denmark, and low levels in relatively fragmented financial systems such as the United States and Germany. The market-concentration issue is perhaps best considered separately for wholesale and retail financial services.

With respect to wholesale financial services, the competitive structure that prevails in the euro-zone is likely to be similar to that prevailing in the global market. National markets for wholesale financial services in the euro-zone countries are already increasingly contested, with corporate and institutional clients under pressure to find the best and most competitively-priced products regardless of vendor. American and other European firms have achieved impressive incursions on traditional domestic client

\footnotetext{
${ }^{3}$ In the case of Canada, two megamergers that would have reduced the number of major financial firms from five to three was disallowed by the authorities in late 1998 despite arguments by management that major American financial services firms would provide the necessary competitive pressure to prevent exploitation of monopoly power.

${ }^{4}$ The Herfindahl-Hirshman index is the sum of the squared market shares $\left(H=3 s^{2}\right)$, where $0<H<10,000$ and market shares are measured for example, by deposits, by assets, or by capital. $\mathrm{H}$ rises as the number of competitors declines and as market-share concentration rises among a given number of competitors.
} 
Table 3

Concentration Trends in the U.S. Financial Services Industry

Number of firms and percent)

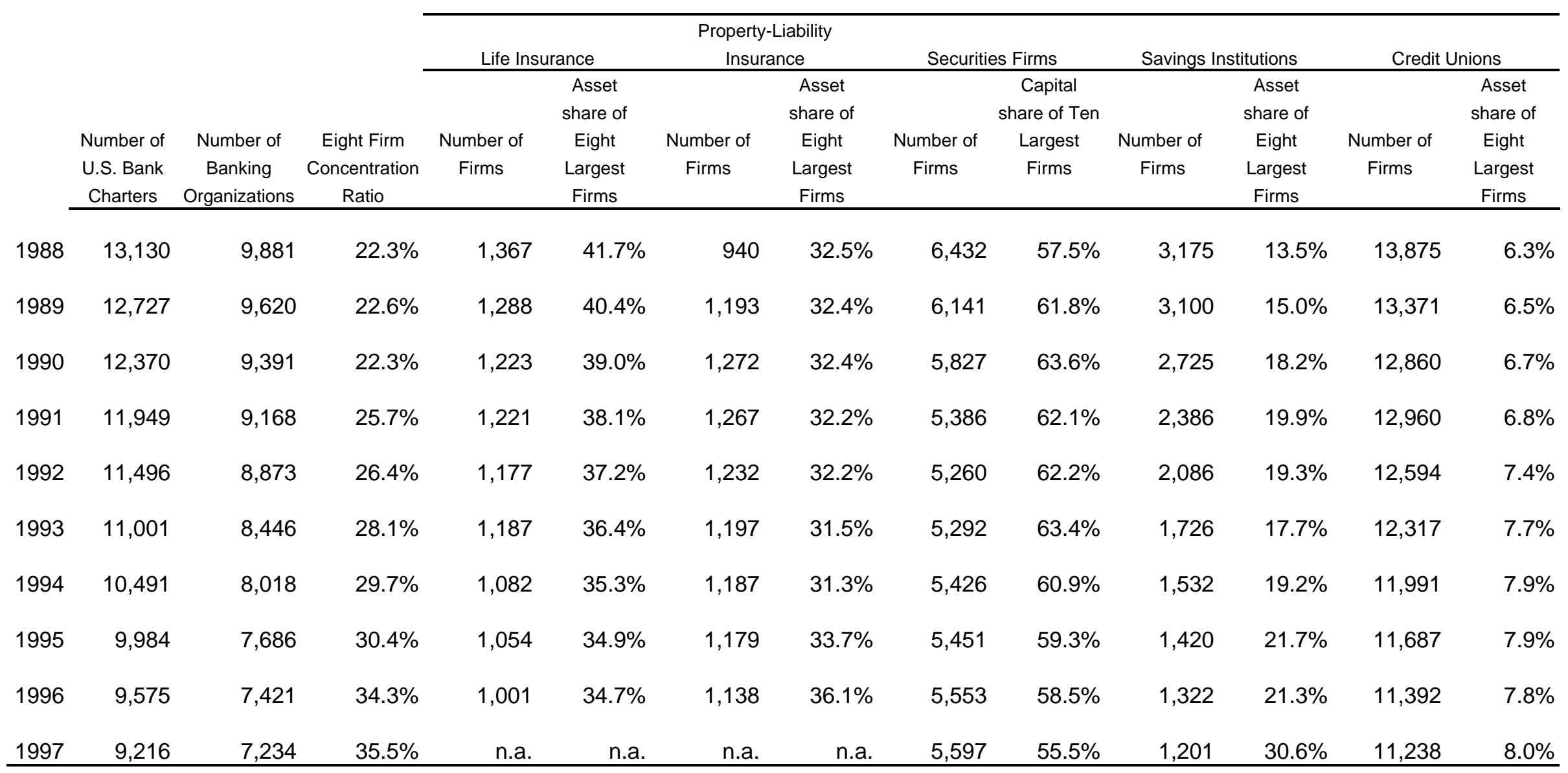

Source: Allen N. Berger, Rebecca S. Demsetz and Philip E. Strahan, The Consolidation of the Financial Services Industry: Causes, Consequences, and Implications for the Future (New York: Federal Reserve Bank of New York, 1998). 
relationships. This is likely to be reinforced by the euro. The pan-European wholesale banking market should be highly fluid, as has long been the case in the United States.

The top-10 firms in global fixed-income and equity underwriting, loan syndications and M\&A mandates in 1997 ranged from U.S. broker-dealers like Merrill Lynch, Goldman Sachs and Morgan Stanley Dean Witter to multifunctional financial conglomerates like UBS, Deutsche Bank and Citigroup - see Annex 2. The dominance of the U.S. firms is evident from this data. Of the top-10 firms, eight were American, two were European and none was Japanese. Of the top-20 firms, 13 were American, seven were European and none was Japanese. The 1998 announced merger of Citicorp and Travelers would have moved its combined market share to No. 2 in the 1997 rankings, and the acquisition of Bankers Trust by Deutsche Bank would have moved the combined firm to No. 10 in the rankings. This picture may shift in the years ahead, as the major European universal banks acquire or build significant wholesale marketshares against their American rivals - especially if introduction of the euro and higher levels of capital-market integration creates disproportionate growth Europe's share of global transaction-flow.

A significant number of firms below the top-10 have the ambition to move up in the rankings. Indeed, global wholesale banking shows very little evidence so far of systematically increasing market concentration to levels capable of supporting sustained excess returns. The Herfindahl-Hirshman index for the top 10 firms rose gradually since 1990, but was still only 572 in 1997. For the top 20 firms, the index rose from 430 in 1995 to 621 in 1997. But the index is still very low compared with many other industries, indicating a high level of market competition despite some evidence of an rising trend in concentration. This indicates a very competitive global wholesale market prevailing well into the future, one that is far tougher than the term "global bulge bracket" - a small coterie of highly profitable global firms - suggests. ${ }^{5}$

With respect to wholesale financial services, competitive conditions that will exist in the global market are likely to exist in the euro-zone as well, which suggests a highly competitive market structure for the foreseeable future. This is good news for the eurozone financial system as a whole, but not such good news for shareholders expecting sustained high profitability from wholesale banking activities. Nor is there much evidence so far that size as conventionally measured (e.g., by assets or capital) makes much difference in determining wholesale banking market share.

The situation is likely to be very different with respect to market structure in retail financial services. Here the geography of local and regional market concentration is clearly more important, and what will no doubt be a very low euro-zone HerfindahlHirshman index for retail banking, insurance and investment services as a whole can mask high levels of regional or local concentration that are capable of supporting monopolistic pricing. The key question here is whether the advent of euro will trigger the kind of geographic cross-penetration observed in the United States after the relaxation

${ }^{5}$ Such data, of course, mask much higher concentration levels in specific areas of wholesale banking activity. But with the exception of initial public offerings (IPOs) the evidence of margin erosion is compelling, suggesting highly contestable global sub-markets that are likely to prevail well into the future. 
of interstate banking restrictions in the 1990s. ${ }^{6}$ American retail financial services markets have become increasingly contestable, with large national and superregional banking networks like Bank of America, Key Corp., Fleet Financial and First Union battling it out for regional market-share with smaller, local institutions surprisingly adept at survival. Table 3 shows that, among all types of financial services firms doing business with the general public, only banks and savings institutions have shown significant increases in concentration (8-firm ratio) during the period 1988-97 - from $22.3 \%$ to $35.5 \%$ - while concentration has decreased substantially in the life insurance industry. Even in the case of banks, the Herfindahl-Hirshman index has decreased from 2,020 in 1988 to 1,949 in 1997 in urban areas, and from 4,316 to 4,114 in non-urban areas - this during a period of dramatic industry consolidation in the United States.

Recent research [Kwast, Starr-McCluer and Wolken, 1997] shows that retail banking clients remain strongly dependent on financial services firms with a local presence, and where there is a high level of concentration this is reflected in both interest rates and deposit rates. [Berger and Hannan, 1987] However, the most profitable firms in the industry were not clearly identified with highly concentrated markets, suggested that other competitive factors seem to be more important. On the other hand, bank mergers that increased local concentration sufficiently to trigger antitrust guidelines of the Department of Justice (a Herfindahl-Hirshman index exceeding 1800 and a 200-point increase in the index as a result of the merger) was associated with reduced deposit rates. [Prager and Hannan, 1999] The U.S. has implemented a legislative constraint against excessive market concentration in the form of the Riegle-Neal Act, which limits the share of retail deposits captured by mergers to $30 \%$ in a given state and $10 \%$ nationally, although these limits do not apply in the case of organic growth. ${ }^{7}$ And despite continued consolidation and capacity reduction in the industry, in 1998 almost 300 new U.S. commercial bank charters were issued. There remains stiff competition from mutual fund companies, broker-dealers and insurance companies as well - i.e., intense competition both within and between strategic groups.

It seems likely that the kind of contestable retail financial services market that exists in the United States will be slower in coming to the euro-zone. Pan-European mass-market branding is not easy to achieve. Local and national consumer preferences remain strong, with no particular reason to change unless there are demonstrable gains in terms of pricing or service quality provided by foreign firms. Nationally entrenched retail financial firms have generally improved their performance to the point that foreign players have a difficult time doing much better, and penetrating local markets by acquisition can be prohibitively expensive. So far, successful cross-border retail businesses are largely in niches like private banking or consumer finance, with broaderbased incursions like Deutsche Bank in Italy or ING in Belgium confined to special situations. Still, change will come, especially with a new generation of consumers less

\footnotetext{
${ }^{6}$ Insurance and investor services were never subject to such restrictions, although there continues to be prudential regulation at the state level.

${ }^{7}$ The merger of BankAmerica and NationsBank in 1998 created a national market share of $8 \%$ for the new Bank of America, which is very close to the limit but can be circumvented by moving assets off the balance sheet or non-deposit funding.
} 
tied to local vendors and new ways of delivering financial services. Markets that are already highly concentrated and characterized by high margins will be increasingly challenged. This suggests that the euro will eventually undermine existing monopolistic market structures, with little prospect of high levels of retail market concentration in the euro-zone as a whole in the foreseeable future.

Finally, the asset management industry (where the top firms comprise a mixture of European, American and Japanese firms and at the same time a mixture of banks, broker-dealers, independent fund management companies and insurance companies see Annex 3) is perhaps the most contestable in the entire financial services industry. Any number can play, as long as they have strong distribution, performance and client service capabilities. With a Herfindahl-Hirshman index of 540 for the top- 40 firms in the industry and very little signs of increasing concentration in recent years, this sector of the euro-zone's financial system is likewise likely to remain highly competitive. Despite this, the quality of earnings in asset management is relatively high, and provides an anchor of stability for financial firms that are also engaged in much more volatile parts of the business.

The role of the state at the national, regional and municipal level will also have a major impact on competitive structure and performance in the euro-zone, and remains rather unclear. The state is far more heavily involved than in the United States, ranging from the European Investment Bank through the German Landesbanken to municipal savings banks. Public guarantees and other forms of support, as well as performance pressures, are very different from those facing investor-owned financial firms. When public- and private-sector firms meet in the market, competitive outcomes will clearly be affected. Consequently, the value extracted from a given market structure may be substantially smaller than expected in the presence of explicit or implicit subsidies imbedded in the activities of state-linked firms in the market. Similar points could be made with respect to cooperatives and mutuals, which play a major role across much of the euro-zone.

One can conclude that the euro is unlikely to have much of an impact on market concentration in wholesale financial services, which is basically a globalized industry, or in asset management. At the same time, it may gradually reduce regional and local market concentration by introducing new competitors. If this is correct, a good proportion of the gains associated with restructuring and competitive development in the euro-zone financial services sector will flow to end-users rather than shareholders. This will place an even greater premium on astute strategic positioning and execution on the part of financial firms. 


\section{Universal banking versus specialist institutions}

\subsection{Firm Structure and Financial Stability}

Proponents of universal banking as the dominant current and future form of strategic organization of financial services argue that the aforementioned operating economies and synergies, as well as non-destructive competition, can best be assured if the core of the evolving financial system in the euro-zone comprises bank-based multifunctional financial organizations [van den Brink, 1998].

There is also the argument that greater diversification of income from multiple products, client-groups and geographies creates more stable, safer, and ultimately more valuable institutions. Indeed, there is some evidence that this is the case. Saunders and Walter [1994] carried out a series of simulated mergers between U.S. banks, securities firms and insurance companies in order to test the stability of earnings of the "merged" as opposed to separate institutions. The opportunity-set of potential mergers between existing firms and the risk-characteristics of each possible combination were examined. The findings suggest that there are indeed potential risk-reduction gains from diversification in multi-activity financial services organizations, and that these gains increase with the number of activities undertaken. The main risk-reduction gains appear to arise from combining commercial banking with insurance activities, rather than with securities activities. Such empirical studies may exaggerate the risk-reduction benefits of universal banking because they ignore many of the operational costs involved in setting up and managing these activities. ${ }^{8}$

It has also been argued that shares of European-type universal banks, incorporate substantial franchise value due to their conglomerate nature and importance in national economies, which Demsetz, Saidenberg and Strahan [1996] suggest serve to inhibit extraordinary risk-taking. They find substantial evidence that the higher a bank's franchise value, the more prudent management tends to be, so that large universal banks with high franchise values should serve shareholder interests as well as stability of the financial system - and the concerns of its regulators - with a strong focus on risk management, as opposed to banks with little to lose. This conclusion is, of course, at variance with the observed, massive losses incurred by European universal banks in recent years in lending to highly leveraged firms, real estate lending and emerging market transactions.

It is certainly the case that a number of large financial institutions will play a major role in the future financial configuration of the euro-zone. Failure of one of these institutions is likely to cause unacceptable systemic consequences, and the institution is virtually certain to be bailed-out by taxpayers - as happened in the case of comparatively much smaller institutions in the United States, Switzerland, Norway, Sweden, Finland, and Japan during the 1980s and early 1990s. ${ }^{9}$ Consequently, too-big-

That is, only the financial firms in existence for the full 1984-88 period are considered.

${ }^{9}$ The speed with which the central banks and regulatory authorities reacted to the 1996 Sumitomo copper trading scandal signaled the possibility of safety-net support of the global copper market, in view of major banks' massive exposures in highly complex structured credits. 
to-fail (TBTF) guarantees create a potentially important public subsidy for universal banking organizations.

Of course, "free lunches" usually don't last too long, and sooner or later such guarantees invariably come with strings attached. Possible regulatory responses include tighter limits on credit- and market-risk exposures, stronger supervision and surveillance intended to achieve "early closure" in advance of capital depletion, and structural barriers to force activities into business units that can be effectively supervised in accordance with their functions even at the cost of a lower levels of $\mathrm{X}$ efficiency and scope economies.

\subsection{Conflicts of Interest}

The potential for conflicts of interest is endemic to the kinds of multifunctional financial services firms that characterize the euro-zone, and runs across the various types of activities in which they are engaged. ${ }^{10}$

First, when firms have the power to sell affiliates' products, managers may no longer dispense "dispassionate" advice to clients and have a salesman's stake in pushing "house" products, possibly to the disadvantage of the customer. Second, a financial firm that is acting as an underwriter and is unable to place the securities in a public offering may seek to ameliorate this loss by "stuffing" unwanted securities into accounts over which it has discretionary authority. Third, a bank with a loan outstanding to a client whose bankruptcy risk has increased, to the private knowledge of the banker, may have an incentive to induce the corporation to issue bonds or equities to the general public, with the proceeds used to pay-down the bank loan. ${ }^{11}$ Fourth, in order to ensure that an underwriting goes well, a bank may make below-market loans to thirdparty investors on condition that the proceeds are used to purchase securities underwritten by its securities unit. Fifth, a bank may use its lending power activities to coerce a client to also use its securities or securities services. Finally, by acting as a lender, a bank may become privy to certain material inside information about a customer or its rivals that can be used in setting prices, advising acquirors in a contested acquisition or helping in the distribution of securities offerings underwritten by its securities unit.

Mechanisms to control conflicts of interest can be market-based, regulationbased, or some combination of the two.

In most of the euro-zone countries few impenetrable walls exist between banking and securities departments within universal banks, and few external firewalls exist between a universal bank and its non-bank subsidiaries (e.g., insurance)..$^{12}$ Internally,

\footnotetext{
${ }^{10}$ For a detailed discussion, see Saunders and Walter [1994], Chapter 6.

${ }^{11} \mathrm{~A}$ recent example is the 1995 underwriting of a secondary equity issue of the Hafnia Insurance Group by Den Danske Bank, distributed heavily to retail investors, with proceeds allegedly used to pay-down bank loans even as Hafnia slid into bankruptcy. This case is now before the courts. See Smith and Walter [1997B].

12 For a comprehensive catalog of potential conflicts of interest, see Gnehm and Thalmann [1989].
} 
there appears to be a reliance on the loyalty and professional conduct of employees, both with respect to the institution's long-term survival and the best interests of its customers. Externally, reliance appears to be placed on market reputation and competition as disciplinary mechanisms. The concern of a bank for its reputation and fear of competitors are viewed as enforcing a degree of control over the potential for conflict exploitation. The United States, on the other hand, has had a tendency since the 1930s to rely on regulation, and in particular on "walls" between types of activities. Either way, preventing conflicts of interest is an expensive business. Compliance systems are costly to maintain, and various types of walls between business units can have high opportunity costs because of inefficient use of information within the organization. ${ }^{13}$

The conflict of interest issue may seriously limit effective strategic options. For example, inside information accessible to a bank as lender to a target firm would almost certainly prevent it from acting as an adviser to a potential acquirer. Entrepreneurs are unlikely to want their private banking affairs dominated by a bank that also controls their business financing. A mutual fund investor is unlikely to have easy access to the full menu of available equity funds though a universal bank offering competing in-house products. These issues may be manageable if most of the competition is coming from other universal banks. But if the playing field is also populated by aggressive insurance companies, broker-dealers, fund managers and other specialists, these issues will prove to be a continuing strategic challenge to management.

\subsection{A Conglomerate Discount?}

It is often argued that the shares of multi-product firms and business conglomerates tend (all else equal) to trade at prices lower than shares of more narrowly-focused firms. There are two reasons why this "conglomerate discount" is alleged to exist.

First it is argued that, on the whole, conglomerates tend to use capital inefficiently. Empirical work by Berger and Ofek [1995] assesses the potential benefits of diversification (greater operating efficiency, less incentive to forego positive net present value projects, greater debt capacity, lower taxes) against the potential costs (higher management discretion to engage in value-reducing projects, crosssubsidization of marginal or loss-making projects that drain resources from healthy businesses, mis-alignments in incentives between central and divisional managers). The authors demonstrate an average value-loss in multi-product firms on the order of $13-15 \%$, as compared to the stand-alone values of the constituent businesses for a sample of U.S. corporations during the period 1986-91. This value-loss was smaller in cases where the multi-product firms were active in closely-allied activities within the same two-digit standard industrial code (SIC) classification.

The bulk of value-erosion in conglomerates is attributed by the authors to overinvestment in marginally profitable activities and cross-subsidization. In empirical work using event-study methodology, John and Ofek [1994] show that asset sales by

13 A detailed discussion is contained in Smith and Walter [1997A], Chapter 8. 
corporations result in significantly improved shareholder returns on the remaining capital employed, both as a result of greater focus in the enterprise and value-gains through high prices paid by asset buyers.

Such empirical findings from event-studies of broad ranges of industry may well apply to diversified activities carried out by financial firms as well. If retail banking and wholesale banking are evolving into highly-specialized, performance-driven businesses, one may ask whether the kinds of conglomerate discounts found in industrial firms may not also apply to universal banking structures, especially as centralized decision-making becomes increasingly irrelevant to the requirements of the specific businesses.

A second possible source of a conglomerate discount is that investors in shares of conglomerates find it difficult to "take a view" and add pure sectoral exposures to their portfolios. Investors may avoid such stocks in their efforts to construct efficient assetallocation profiles. This is especially true of highly performance-driven managers of institutional equity portfolios who are under pressure to outperform cohorts or equity indexes. So the portfolio logic of a conglomerate discount may indeed apply in the case of a multifunctional financial firm that is active in retail banking, wholesale commercial banking, middle-market banking, private banking, corporate finance, trading, investment banking, asset management and perhaps other businesses. In effect, a financial conglomerate shares are a closed-end mutual fund of a broad range of assets.

Both the portfolio-selection and capital-misallocation effects (perhaps mitigated by the franchise and TBTF effects mentioned earlier) may thus weaken investor demand for financial conglomerate shares, and lower their equity prices. In the context the euro-zone universal banks and other financial conglomerates, management will have to come up with a compelling set of counter-arguments, particularly when investors have the choice of placing their bets on more narrowly-focused financial specialists.

\subsection{Linkages Between Financial and Nonfinancial Firms}

In most of the euro-zone countries, including France and Germany, banks and insurance companies have traditionally held large-scale shareholdings in nonfinancial corporations or have been part of multi-industry holdings of financial groups. There are various historical reasons for this, such as politically-driven interests of the state to intervene directly in the control of industry and past economic crises that forced banks to capitalize debt in the face of threatened client bankruptcies. There are also portfolio reasons, such as the need of insurance companies to invest massive reserves in the absence of sufficiently broad and deep local capital markets - inevitably leading to major equity positions in nonfinancial corporations as well as banks. And there are relationship reasons, with banks viewing shareholdings in client firms as an important part of "Hausbank" ties that would attract most of the client's financial services business, even as clients themselves value the presence of a reliable lender who looks beyond a purely arm's length credit relationship.

The absence of efficient capital markets in many European countries has historically produced a powerful role for the types of "internal" capital markets that can 
be seen in industrial conglomerates, long-term cross shareholdings, equity stakes cementing strategic alliances and other institutional and financial ties between banks, insurance companies and industrial companies. Of course, the causality can run the other way too, with European-style "insider" relationships tending to perpetuate themselves. This will impede the development of alternatives such as commercial paper markets, corporate bond markets, and strong equity markets capable of attracting broad stock holdings on the part of individuals, pension funds and mutual funds. This in turn will limit shareholder-value pressures and periodic governance challenges to corporate underperformance though hostile corporate action.

The value of bank shareholdings in industrial firms or insurance companies is, of course, embedded in the market price of bank shares. The combined value of the bank itself and its industrial shareholdings may be larger or smaller than the sum of their stand-alone values. For example, Hausbank ties to corporations in which a bank has significant financial stakes and a direct governance role may raising the value of the bank. On the other hand, if such "tied" sourcing of financial services raises the cost of capital facing client corporations, this will in turn reduce the value of bank's own shareholdings. The reverse may be true if such ties lower client firms' cost of capital. Permanent bank shareholdings may also stunt the development of a contestable market for corporate control, thereby impeding corporate restructuring and depressing competitive performance and stock prices, which in turn are reflected in the value of the bank to its shareholders. Banks may also be induced to lend to affiliated corporations under credit conditions that would be rejected by unaffiliated lenders, and possibly encounter other conflicts of interest that may ultimately make it more difficult to maximize shareholder value.

In effect, a shareholder of euro-zone banks with significant industrial participations obtains a closed-end mutual fund that has been assembled by bank managers for various reasons over time, and may bear no relationship to the investor's own portfolio optimization goals. The value of the bank itself then depends on the total market value of its shares, which must be held on an all-or-nothing basis, plus its own market value.

Bank-industry linkages have for some time been subject to reexamination in many of the euro-zone countries, especially in terms of their impact on economic restructuring and overall economic performance in comparison with the more capitalmarket oriented "Anglo-American" approach. Even without the U.K. as a founding member of the euro-zone, companies like DaimlerChrysler, VEBA, Aegon and Alcatel have exposed themselves to market-based shareholder-value discipline, even as developments are underway that may ultimately lead to a pan-European equity market capable to meeting the needs of massive performance-driven institutional pension funds and mutual funds. And there is a clear tendency toward loosening bank-industry ties, both on the part of corporations seeking better access to financing and advice and on the part of bankers seeking to manage their equity portfolios more actively - most notably in the establishment of DB Investor by Deutsche Bank late in 1998. So it seems clear how the "battle of the systems" of corporate governance is running, with a panEuropean capital market-based approach likely to carry the day. ${ }^{14}$

\footnotetext{
${ }^{14}$ See Walter [1993] and Story and Walter [1997].
} 


\section{Strategic Options}

The foregoing discussion is centered around a common-sense approach to strategic positioning and execution after the launch of the euro. Put simply, it's all a matter of doing the right thing, and then doing it right. This invariably requires an astute assessment of the prospective competitive battlefield, both in terms of market prospects and competitive structures, which has to be based on a number of suppositions reflecting a well-argued consensus among those creating the strategy. If important suppositions turn out to be wrong, key parts of the strategy will be wrong too.

Once a judgment has been reached as to key client-groups, geographies and product portfolios that may promise to generate acceptable risk-adjusted returns to shareholders, a strategic configuration has to be devised for the institution that can extract significant scale and scope economies and that can be managed effectively to achieve strong operating economies. Such an optimum configuration may be termed "strategic integrity." It forms what the Germans call a "soll-Zustand" (what ought to be). This has to compared with the "ist-Zustand" (what is), i.e., how does the institution currently stack-up against all competitors, traditional and nontraditional, in the cold light of day, and what will be required to compete effectively in the future in terms of capital, human and managerial resources and organizational change.

Realistically comparing reality to strategic objectives in the presence of a critical time element usually produces a number of show-stoppers. Rejecting losers among strategic options is just as important as selecting winners, and is often much more difficult - especially when opportunistic moves beckon and time is short. Failure to reject losers probably results in a disproportionate number of what turn out to be strategic errors in the financial services sector - often at great expense to shareholders.

Finally comes strategic implementation: Marshaling resources, controlling costs, getting the troops on board, building a high-performance "super-culture" over what inevitably will be a number of often very different "sub-cultures," getting the right people, and then providing effective leadership. The devil is always in the details.

If a strategic direction taken by the management of a financial firm in the eurozone does not exploit every source of potential value for shareholders, then what is the purpose? Avoiding an acquisition attempt from a better-managed suitor who will pay a premium price does not seem nearly as unacceptable today as it may have been in the past. In a world of more open and efficient markets for shares in financial institutions, shareholders increasingly tend to have the final say about the future of their enterprises. 


\section{References}

Akhavein, Jalal D., Allen N. Berger and David B. Humphrey, "The Effects of Megamergers on Efficiency and Prices: Evidence from a Bank Profit Function," paper presented at a Conference on Mergers of Financial Institutions, New York University Salomon Center, October 11, 1996.

Berger, Allen N., Rebecca S. Demsetz and Philip E. Strahan, The Consolidation of the Financial Services Industry: Causes, Consequences, and Implications for the Future (New York: Federal Reserve Bank of New York, 1998).

Berger, Allen N., Diana Hancock and David B. Humphrey, "'Bank Efficiency Derived from the Profit Function," Journal of Banking and Finance, April 1993.

Berger, Allen N. and T.H. Hannan, "The Price-Concentration Relationship in Banking," Review of Economics and Statistics, 71, 1987.

Berger, Allen N., William C. Hunter and Stephen J. Timme, "The Efficiency of Financial Institutions: A Review of Research Past, Present and Future," Journal of Banking and Finance, April 1993.

Berger, Allen M. and L. Mester, "Inside the Black Box: What Explains Differences in the Efficiencies of Financial Institutions?" Journal of Banking and Finance, 21, 1997.

Berger, Philip G. and Eli Ofek, "Diversification's Effect on Firm Value," Journal of Financial Economics, 37, 1995.

Cummins, J.D. and H. Zi, "Comparisons of Frontier Efficiency Levels," Journal of Productivity Analysis, June 1998.

DeLong, Gayle, Roy C. Smith and Ingo Walter, M\&A Database: Financial Services, New York University Salomon Center, 1999.

Demsetz, Rebecca S., Marc R. Saidenberg and Philip E. Strahan, "Banks with Something to Lose: The Disciplinary Role of Franchise Value," Federal Reserve Bank of New York Policy Review, October 1996.

Gnehm, A. and C. Thalmann, "Conflicts of Interest in Financial Operations: Problems of Regulation in the National and International Context," Working Paper, Swiss Bank Corporation, Basel, 1989.

Goldberg, L.G., G.A. Hanweck, M. Keenan and A. Young, "Economies of Scale and Scope in the Securities Industry," Journal of Banking and Finance, 15, 1991.

John, Kose and Eli Ofek, "Asset Sales and Increase in Ficus," Journal of Financial Economics, 37, 1995. 
Kwast, M.L., M. Starr-McCluer and J. Wolken, "Market Definition and the Analysis of Antitrust in Banking," Antitrust Bulletin, 42, 973-995, 1997.

Lang, G. and P. Wetzel, "Technology and Cost Efficiency in Universal Banking: A Thick Frontier Approach," Journal of Productivity Analysis, 10, 1998.

Prager, R.A. and T. H. Hannan, "Do Substantial Horizontal Mergers Generate Significant Price Effects?" Journal of Industrial Economics, 1999 - forthcoming.

Saunders, Anthony, Financial Institutions Management, Second Edition (Burr Ridge, III.: Irwin, 1996).

Saunders, Anthony and Ingo Walter, Universal Banking in the United States (New York: Oxford University Press, 1994).

Siems, Thomas F. "Bank Mergers and Shareholder Value: Evidence from 1995's Megamerger Deans," Federal Reserve Bank of Dallas Financial Industry Studies, August 1996.

Smith, Roy C. and Ingo Walter, Global Banking (New York: Oxford University Press, 1997A).

Smith, Roy C. and Ingo Walter, Street Smarts: Leadership and Shareholder Value in the Securities Industry (Boston: Harvard Business School Press, 1997B).

Story, Jonathan and Ingo Walter, Political Economy of Financial Integration in Europe: The Battle of the Systems (Manchester: Manchester University Press, and Cambridge: MIT Press, 1997).

Van den Brink, R.G.C., "Universal Banking: An Answer to the Challenges Facing the Financial Sector," ABN AMRO (mimeo.) 1998.

Walter, Ingo, Global Competition in Financial Services (Cambridge: Ballinger-Harper \& Row, 1988).

Walter, Ingo, The Battle of the Systems: Control of Enterprises in the Global Economy (Kiel: Kieler Studien Nr. 122, Institut für Weltwirtschaft, 1993).

Walter, Ingo, "The Asset Management Industry in Europe: Competitive Structure and Performance Under EMU," in Jean Dermine and Pierre Hillion (eds.) European Capital Markets With a Single Currency (Oxford: Oxford University Press, 1999). 
Annex 1 - Table A

Top-20 U.S. Bank Performance Data, November 1998

\begin{tabular}{|c|c|c|c|c|c|c|c|c|}
\hline Bank & $\begin{array}{c}\text { Total Assets } \\
\text { (\$ billions) }\end{array}$ & $\begin{array}{l}\text { Market cap } \\
\text { (\$ billions) } \\
\end{array}$ & $\begin{array}{c}\text { Market Cap } \\
\text { as } \% \text { of Assets }\end{array}$ & $\begin{array}{l}\text { Tier } 1 \\
\text { Equity }\end{array}$ & $\begin{array}{c}\text { ROAE } \\
\text { (post tax) }\end{array}$ & $\begin{array}{l}\text { Net Int } \\
\text { Margin }\end{array}$ & P./E & P/B \\
\hline 1 Citigroup & 702 & 107.0 & $15.2 \%$ & 8.3 & 6.5 & 5.1 & n.a. & n.a. \\
\hline 2 Chase Manhattan & 357 & 48.7 & $13.6 \%$ & 8.3 & 14.9 & 3.1 & 13.2 & 2.20 \\
\hline 3 JP Morgan & 299 & 16.6 & $5.6 \%$ & 7.4 & 5.3 & 0.7 & 17.3 & 1.68 \\
\hline 4 BankAmerica & 264 & 99.9 & $37.8 \%$ & 7.4 & 7.7 & 3.6 & 14.6 & 2.12 \\
\hline 5 First Union & 235 & 57.4 & $24.4 \%$ & 7.1 & 23.5 & 3.8 & 15.5 & 3.31 \\
\hline 6 Norwest/Wells Fargo & 196 & 50.0 & $25.5 \%$ & n.a. & n.a. & n.a. & n.a. & n.a. \\
\hline 7 Bankers Trust & 156 & 6.0 & $3.8 \%$ & 7.0 & n.a. & 1.0 & 8.7 & 1.44 \\
\hline 8 BancOne & 120 & 57.3 & $47.8 \%$ & 9.2 & 21.8 & 5.3 & 14.4 & 2.81 \\
\hline 9 Fleet Financial & 100 & 22.7 & $22.7 \%$ & 6.9 & 18.6 & 4.6 & 15.5 & 2.68 \\
\hline 10 National City & 83 & 21.2 & $25.5 \%$ & 8.8 & 19.0 & 4.1 & 16.2 & 2.94 \\
\hline 11 Key Corp & 78 & 13.3 & $17.1 \%$ & 6.7 & 18.1 & 4.2 & 13.7 & 2.38 \\
\hline 12 PNC Bank & 76 & 15.1 & $19.9 \%$ & 7.4 & 20.5 & 3.8 & 15.4 & 2.75 \\
\hline 13 BankBoston & 74 & 10.8 & $14.6 \%$ & 7.0 & 16.3 & 4.0 & 12.5 & 2.30 \\
\hline 14 Bank of NY & 64 & 23.6 & $36.9 \%$ & 7.5 & 24.2 & 3.2 & 20.6 & 4.76 \\
\hline 15 Wachovia & 66 & 18.7 & $28.3 \%$ & 8.1 & 18.2 & 6.2 & 20.4 & 3.52 \\
\hline 16 Sun Trust Bank & 61 & 14.6 & $23.9 \%$ & 7.2 & 13.3 & 3.9 & 19.6 & 2.79 \\
\hline 17 State Street & 51 & 10.1 & $19.8 \%$ & 14.3 & 20.0 & 1.8 & 23.4 & 4.51 \\
\hline 18 Mellon Bank & 48 & 15.7 & $32.7 \%$ & 6.8 & 20.3 & 4.0 & 18.5 & 3.60 \\
\hline 19 SouthTrust & 36 & 6.0 & $16.7 \%$ & 6.8 & 14.4 & 3.7 & 14.3 & 2.27 \\
\hline 20 Comerica & 34 & 10.0 & $6.5 \%$ & 7.2 & 23.0 & 4.6 & 17.2 & 3.73 \\
\hline Total & 3100.0 & 624.7 & $20.2 \%$ & & & & & \\
\hline Average Top 20 & 155.0 & 40.5 & $21.0 \%$ & 7.6 & 15.7 & 3.6 & 14.3 & 2.4 \\
\hline U.S. Banks Average & & & & 8.6 & 16.2 & 3.7 & 15 & 2.85 \\
\hline
\end{tabular}

Source: Goldman Sachs \& Co. 
Annex 1 - Table B

Top-20 European Bank Performance Data, November 1998

\begin{tabular}{|c|c|c|c|c|c|c|c|c|c|}
\hline Bank & $\begin{array}{c}\text { Total Assets } \\
\text { (\$ billions) }\end{array}$ & $\begin{array}{l}\text { Market cap } \\
\text { (\$ billions) }\end{array}$ & $\begin{array}{c}\text { Market Cap } \\
\text { as \% of Assets }\end{array}$ & $\begin{array}{l}\text { Tier } 1 \\
\text { Equity }\end{array}$ & $\begin{array}{c}\text { ROAE } \\
\text { (post tax) }\end{array}$ & $\begin{array}{l}\text { Net Int } \\
\text { Margin }\end{array}$ & $\begin{array}{l}\text { Ln growth } \\
8 \text { years }\end{array}$ & P./E & P/B \\
\hline 1 UBS & 749 & 69.2 & $9.24 \%$ & 7.5 & 21.6 & 1.0 & n.a. & 15.50 & 2.94 \\
\hline 2 Deutsche Bank & 693 & 33.4 & $4.82 \%$ & 5.1 & 15.0 & 1.3 & 11.9 & 11.70 & 1.76 \\
\hline 3 ABN-Amro & 501 & 31.8 & $6.35 \%$ & 7.2 & 18.3 & 1.7 & 28.1 & 16.00 & 2.12 \\
\hline 4 Hypovereinsbank & 492 & 31.3 & $6.36 \%$ & 5.0 & 17.7 & 1.3 & n.a. & n.a. & n.a. \\
\hline 5 HBSC & 487 & 55.5 & $11.40 \%$ & 9.8 & 17.7 & 2.8 & n.a. & 12.00 & 2.02 \\
\hline 6 Credit Suisse & 477 & 46.4 & $6.56 \%$ & 10.3 & 2.2 & 0.9 & 13.1 & 18.60 & 3.2 \\
\hline 7 Dresdner & 462 & 24.7 & $5.35 \%$ & 5.7 & 15.0 & 1.3 & 8.5 & 19.70 & 2.04 \\
\hline 8 ING Groep & 456 & 55.2 & $12.11 \%$ & 7.0 & 13.5 & 2.3 & 17.0 & 15.60 & 1.47 \\
\hline 9 Societe Generale & 418 & 18.2 & $4.35 \%$ & 6.2 & 10.4 & 1.2 & 9.5 & 13.50 & 1.65 \\
\hline 10 Barclays & 406 & 35.6 & $8.77 \%$ & 7.3 & 22.9 & 3.4 & -0.5 & 12.20 & 2.70 \\
\hline 11 Banque Nationale des Paris & 346 & 14.6 & $4.22 \%$ & 5.5 & 10.1 & 1.1 & 4.6 & 12.40 & 1.39 \\
\hline 12 Commerzbank & 343 & 13.8 & $4.02 \%$ & 6.0 & 10.4 & 1.3 & 14.6 & 13.90 & 1.37 \\
\hline 13 National Westminster & 311 & 30.2 & $9.71 \%$ & 8.1 & 18.6 & 3.3 & 1.2 & 12.80 & 2.37 \\
\hline 14 San Paolo-IMI & 200 & 12.0 & $6.00 \%$ & 11.0 & 5.2 & 1.8 & 11.8 & 20.80 & 2.25 \\
\hline 15 Lloyds TSB & 234 & 64.8 & $27.69 \%$ & 9.1 & 27.7 & 3.6 & 10.0 & 18.10 & 5.49 \\
\hline 16 Santander & 186 & 21.9 & $11.77 \%$ & 8.3 & 22.2 & 2.6 & 30.2 & 19.90 & 3.33 \\
\hline 17 BBV & 147 & 26.9 & $18.30 \%$ & 9.0 & 19.4 & 2.9 & 10.6 & 25.00 & 4.88 \\
\hline 18 Bank Austria & 126 & 6.9 & $5.48 \%$ & 5.9 & 8.5 & 1.5 & n.a. & 6.40 & 1.07 \\
\hline 19 Banco di Roma & 119 & 10.3 & $8.66 \%$ & 6.9 & n.a. & 2.4 & n.a. & 16.80 & 1.80 \\
\hline $20 \mathrm{BCl}$ & 117 & 12.0 & $10.26 \%$ & 7.8 & 5.1 & 2.9 & 12.2 & 23.40 & 2.32 \\
\hline Total & 7270 & 614.7 & $8.46 \%$ & & & & & & \\
\hline UK \& Continental Avg. & & & & 7.4 & 14.6 & 1.7 & 10.9 & 14.5 & 2.06 \\
\hline
\end{tabular}

Source: Goldman Sachs \& Co. 


\section{Annex 2: Global Wholesale Banking and Investment Banking 1998 Full Credit to Book Running Manager Only}

(\$ millions)

\begin{tabular}{|c|c|c|c|c|c|c|}
\hline Firm (1997 Ranking) & $\begin{array}{l}\text { Global Securities } \\
\text { Underwriting and } \\
\text { Private Placements } \\
\end{array}$ & $\begin{array}{c}\text { Global M\&A } \\
\text { Advisory (a) }\end{array}$ & $\begin{array}{l}\text { International Bank } \\
\text { Loans Arranged }\end{array}$ & $\begin{array}{c}\text { Medium Term } \\
\text { Notes Lead } \\
\text { Managed (b) } \\
\end{array}$ & Total & $\begin{array}{l}\text { Percent of } \\
\text { Top } 25 \text { (c) }\end{array}$ \\
\hline Goldman Sachs \& Co (2) & $388,765.9$ & $1,067,258.8$ & $16,404.5$ & $54,419.6$ & $1,526,848.8$ & $13.89 \%$ \\
\hline Merrill Lynch \& Co (1) & $549,797.3$ & $692,920.3$ & $10,999.7$ & $129,629.4$ & $1,383,346.7$ & $12.59 \%$ \\
\hline Morgan Stanley Dean Witter (4) & $404,497.5$ & $635,623.9$ & & $32,680.2$ & $1,072,801.6$ & $9.76 \%$ \\
\hline Salomon Smith Barney /Citigroup (7/11) & $366,353.8$ & $483,761.8$ & $107,565.7$ & $51,412.2$ & $1,009,093.5$ & $9.18 \%$ \\
\hline Credit Suisse First Boston (6) & $290,502.0$ & $431,756.5$ & $19,086.9$ & $60,166.1$ & $801,511.5$ & $7.29 \%$ \\
\hline JP Morgan \& Co. Inc. (5) & $250,064.7$ & $324,207.0$ & $115,665.7$ & $27,502.8$ & $717,440.2$ & $6.53 \%$ \\
\hline Chase Manhattan Corporation (3) & $122,602.9$ & $172,858.9$ & $307,131.0$ & $20,448.0$ & $623,040.8$ & $5.67 \%$ \\
\hline Lehman Brothers (8) & $264,339.6$ & $225,415.6$ & $26,311.8$ & $48,982.5$ & $565,049.5$ & $5.14 \%$ \\
\hline Deutsche Bank / BT (15/16) & $158,681.0$ & $147,874.4$ & $53,780.3$ & $84,419.0$ & $444,754.7$ & $4.05 \%$ \\
\hline Warburg Dillon Read / UBS (9) & $201,809.6$ & $143,743.3$ & $17,009.9$ & $53,780.1$ & $416,342.9$ & $3.79 \%$ \\
\hline Bank of America Corp (14) & $57,975.7$ & $83,679.4$ & $200,100.1$ & $42,250.0$ & $384,005.2$ & $3.49 \%$ \\
\hline Bear Stearns (12) & $140,608.7$ & $184,752.8$ & & $17,610.0$ & $342,971.5$ & $3.12 \%$ \\
\hline Donaldson, Lufkin \& Jenrette (13) & $111,498.7$ & $217,614.0$ & $12,618.8$ & & $341,731.5$ & $3.11 \%$ \\
\hline ABN AMRO (17) & $127,077.6$ & $34,143.3$ & $16,282.5$ & $125,333.1$ & $302,836.5$ & $2.76 \%$ \\
\hline Paribas / Societe Generale (25/41) & $153,649.0$ & $54,472.3$ & & $11,398.0$ & $219,519.3$ & $2.00 \%$ \\
\hline Lazard Houses (18) & & $160,775.5$ & & & $160,775.5$ & $1.46 \%$ \\
\hline Barclays Capital (19) & $81,236.9$ & & $14,457.3$ & $6,370.2$ & $102,064.4$ & $0.93 \%$ \\
\hline Dresdner Kleinwort Benson (30) & $54,611.5$ & $37,373.2$ & & $8,273.0$ & $100,257.7$ & $0.91 \%$ \\
\hline Rothschild Group (28) & & $84,291.2$ & & & $84,291.2$ & $0.77 \%$ \\
\hline Nomura Securities (34) & $58,998.1$ & & & $14,556.0$ & $73,554.1$ & $0.67 \%$ \\
\hline Schroder Group (22) & & $69,179.4$ & & & $69,179.4$ & $0.63 \%$ \\
\hline BankBoston (38) & & $49,903.0$ & $19,124.8$ & & $69,027.8$ & $0.63 \%$ \\
\hline First Union Corp (39) & $24,972.3$ & & $21,591.7$ & $20,000.0$ & $66,564.0$ & $0.61 \%$ \\
\hline PaineWebber (23) & $57,604.2$ & & & & $57,604.2$ & $0.52 \%$ \\
\hline $\operatorname{HSBC}(24)$ & $57,260.5$ & & & & $57,260.5$ & $0.52 \%$ \\
\hline Top 25 Firms & $3,922,907.5$ & $5,301,604.6$ & $958,130.7$ & $809,230.2$ & $10,991,873.0$ & \\
\hline Top 10 as \% of Top 25 & $76.41 \%$ & $81.59 \%$ & $70.34 \%$ & $69.63 \%$ & $77.88 \%$ & \\
\hline Top 20 as \% of Top 25 & $96.44 \%$ & $97.75 \%$ & $95.75 \%$ & $97.53 \%$ & $97.09 \%$ & \\
\hline
\end{tabular}

(a) Completed deals only. Full credit to both advisors to targets and acquirers.

(b) Equal credit to both book runners if acting jointly.

(c) To avoid overestimation, the top 25 total -- $\$ 10,991,873.0$ mil was used instead of the industry total -- $\$ 8,470,261.3$ mil

Data: Securities Data Corporation 


\section{Annex 2 (Cont'd.): Global Wholesale Banking and Investment Banking 1998 Full Credit to Book Running Manager Only

\author{
(\$ millions)
}

The Next Twenty Two:

\begin{tabular}{|c|c|c|c|c|c|c|}
\hline Firm (1997 Ranking) & $\begin{array}{c}\text { Global Securities } \\
\text { Underwriting and } \\
\text { Private Placements } \\
\end{array}$ & $\begin{array}{l}\text { Global M\&A } \\
\text { Advisory (a) }\end{array}$ & $\begin{array}{c}\text { International Bank } \\
\text { Loans Arranged }\end{array}$ & $\begin{array}{c}\text { Medium Term } \\
\text { Notes Lead } \\
\text { Managed (b) } \\
\end{array}$ & Total & $\begin{array}{c}\text { Percent of } \\
\text { Industry } \\
\text { Total } \\
\end{array}$ \\
\hline CIBC Wood Gundy Securities (27) & $12,594.8$ & $34,321.6$ & $9,308.4$ & & $56,224.8$ & $0.66 \%$ \\
\hline BANK ONE Corp & & & $53,445.1$ & & $53,445.1$ & $0.63 \%$ \\
\hline Wasserstein, Perella (33) & & $40,887.1$ & & & $40,887.1$ & $0.48 \%$ \\
\hline Enskilda Securities & & $40,661.4$ & & & $40,661.4$ & $0.48 \%$ \\
\hline Natwest (20) & $39,208.6$ & & & & $39,208.6$ & $0.46 \%$ \\
\hline RBC Dominion Securities (35) & & $33,489.6$ & & & $33,489.6$ & $0.40 \%$ \\
\hline Prudential Securities (31) & $26,587.5$ & & & & $26,587.5$ & $0.31 \%$ \\
\hline Bank of New York (32) & & & $25,834.9$ & & $25,834.9$ & $0.31 \%$ \\
\hline Toronto-Dominion Bank and $\operatorname{Tr}(40)$ & & & $24,751.1$ & & $24,751.1$ & $0.29 \%$ \\
\hline Commerzbank AG (37) & $11,778.3$ & & & $10,000.0$ & $21,778.3$ & $0.26 \%$ \\
\hline First Tennessee Bank, N.A. & $21,357.4$ & & & & $21,357.4$ & $0.25 \%$ \\
\hline Scotiabank-Bank of Nova Scotia & & & $14,001.0$ & & $14,001.0$ & $0.17 \%$ \\
\hline Daiwa Securities (29) & & & & $13,500.0$ & $13,500.0$ & $0.16 \%$ \\
\hline Banque Nationale de Paris (26) & & & & $11,700.0$ & $11,700.0$ & $0.14 \%$ \\
\hline Fleet Financial Group Inc & & & $10,788.9$ & & $10,788.9$ & $0.13 \%$ \\
\hline ING Barings (36) & $10,623.1$ & & & & $10,623.1$ & $0.13 \%$ \\
\hline Bayerische $\mathrm{H}-\mathrm{V}$ & & & & $10,000.0$ & $10,000.0$ & $0.12 \%$ \\
\hline Bank of Montreal Trust & & & $9,751.9$ & & $9,751.9$ & $0.12 \%$ \\
\hline Sakura Bank, Ltd. & & & & $9,124.3$ & $9,124.3$ & $0.11 \%$ \\
\hline PNC Bank NA & & & $8,146.3$ & & $8,146.3$ & $0.10 \%$ \\
\hline Wells Fargo Bank NA (50) & & & $6,875.8$ & & $6,875.8$ & $0.08 \%$ \\
\hline Banque Internationale Lux SA & & & & $5,744.5$ & $5,744.5$ & $0.07 \%$ \\
\hline
\end{tabular}

(a) Completed deals only. Full credit to both advisors to targets and acquirers.

(b) Equal credit to both book runners if acting jointly.

Data: Securities Data Corporation 
Annex 3

Top Global Money Managers: AUM Execeeding $\$ 100$ Million

(As of April, 1998) *

Total Assets Unde

Management

(millions)

UBS

920,000

Japan Postal Insurance System

865,020

(Tokyo, Japan)

FMR Corp.

515,300

(Boston, MA)

Groupe AXA-UAP

(Paris, France)

Zurich Group

500,300

460,000

(Zurich, Switzerland)

Merrill Lynch \& Co. (incl. MAM)

(New York, NY) - merged Nov. 97

Barclays Bank PLC

(London, UK)

Credit Suisse/Winterthur

(Zurich, Switzerland)

The Prudential Corporation

(London, UK)

Nippon Life Insurance Co.

(Tokyo, Japan)

The Vanguard Group

(Valley Forge, PA)

State Street Boston Corp.

(Boston, MA)

The Prudential Ins. Co. of America

(Newark, NJ)

Capital Group Cos.

(Los Angeles, CA)

Mellon Bank Corp.

(Pittsburg, PA)

Deutsche Bank, AG

(Frankfurt, Germany)

Bankers Trust Co.

450,000

385,449

380,000

350,000

342,800

310,500

300,947

271,700

259,704

258,923

240,000

239,582

(New York, NY)

Morgan Stanley, Dean Witter \& Discover Co.

234,806

(New York, NY)

213,400

(New York, NY)

Total Assets Unde

Management

\begin{tabular}{|c|c|}
\hline & $\begin{array}{l}\text { Total Assets Unde } \\
\text { Management } \\
\text { (millions) }\end{array}$ \\
\hline $\begin{array}{l}\text { Allianz AG } \\
\text { (Munich, Germany) }\end{array}$ & 210,000 \\
\hline $\begin{array}{l}\text { J.P. Morgan \& Co. } \\
\text { (New York, NY) }\end{array}$ & 208,605 \\
\hline $\begin{array}{l}\text { Equitable Life Assurance Society of the U.S. } \\
\text { (New York, NY) }\end{array}$ & 207,999 \\
\hline $\begin{array}{l}\text { Franklin Resources } \\
\text { (San Mateo, CA) }\end{array}$ & 174,954 \\
\hline $\begin{array}{l}\text { Marsh \& McLennan Cos. } \\
\text { (New York, NY) }\end{array}$ & 173,443 \\
\hline $\begin{array}{l}\text { United Asset Management Corp. } \\
\text { (Boston, MA) }\end{array}$ & 168,024 \\
\hline $\begin{array}{l}\text { Putnam Funds } \\
\text { (Boston, MA) }\end{array}$ & 161,000 \\
\hline $\begin{array}{l}\text { American Express Co. } \\
\text { (New York, NY) }\end{array}$ & 147,696 \\
\hline $\begin{array}{l}\text { Internationale Nederlanden Groep } \\
\text { (Amsterdam, The Netherlands) }\end{array}$ & 140,000 \\
\hline $\begin{array}{l}\text { Wellington Management Co. } \\
\text { (Boston, MA) }\end{array}$ & 133,162 \\
\hline $\begin{array}{l}\text { Northern Trust Corp. } \\
\text { (Chicago, IL) }\end{array}$ & 130,252 \\
\hline $\begin{array}{l}\text { Chase Manhattan Corp. } \\
\text { (New York, NY) }\end{array}$ & 130,095 \\
\hline $\begin{array}{l}\text { Invesco Group Ltd. } \\
\text { (London, UK) }\end{array}$ & 126,172 \\
\hline $\begin{array}{l}\text { Nomura Securities Corp. } \\
\text { (Tokyo, Japan) }\end{array}$ & 115,000 \\
\hline $\begin{array}{l}\text { PNC Bank Corp. } \\
\text { (Pittsburg, PA) }\end{array}$ & 110,396 \\
\hline $\begin{array}{l}\text { Pimco Advisors } \\
\text { (Newport Beach, CA) }\end{array}$ & 110,022 \\
\hline $\begin{array}{l}\text { Federated Investors } \\
\text { (Boston, MA) }\end{array}$ & 101,300 \\
\hline T. Rowe Price Associates & 100,390 \\
\hline
\end{tabular}

${ }^{*}$ Assumes completion of UBS and Citigroup 